\title{
Risk of contralateral breast cancer according to first breast cancer characteristics among women in the USA, 1992-2016
}

Cody Ramin ${ }^{1 *}$ D, Diana R. Withrow¹, Brittny C. Davis Lynn², Gretchen L. Gierach² and Amy Berrington de González ${ }^{1}$

\begin{abstract}
Background: Estimates of contralateral breast cancer (CBC) risk in the modern treatment era by year of diagnosis and characteristics of the first breast cancer are needed to assess the impact of recent advances in breast cancer treatment and inform clinical decision making.

Methods: We examined CBC risk among 419,818 women (age 30-84 years) who were diagnosed with a first unilateral invasive breast cancer and survived $\geq 1$ year in the US Surveillance, Epidemiology, and End Results program cancer registries from 1992 to 2015 (follow-up through 2016). CBC was defined as a second invasive breast cancer in the contralateral breast $\geq 12$ months after the first breast cancer. We estimated standardized incidence ratios (SIRs) of CBC by year of diagnosis, age at diagnosis, and tumor characteristics for the first breast cancer. Cumulative incidence of CBC was calculated for women diagnosed with a first breast cancer in the recent treatment era (2004-2015, follow-up through 2016).

Results: Over a median follow-up of 8 years (range 1-25 years), 12,986 breast cancer patients developed CBC. Overall, breast cancer patients had approximately twice the risk of developing cancer in the contralateral breast when compared to that expected in the general population ( $\mathrm{SIR}=2.21,95 \% \mathrm{Cl}=2.17-2.25)$. SIRs for $\mathrm{CBC}$ declined by year of first diagnosis, irrespective of age at diagnosis and estrogen receptor (ER) status ( $p$-trends $<0.001$ ), but the strongest decline was after an ER-positive tumor. The 5-year cumulative incidence of CBC ranged from 1.01\% $(95 \% \mathrm{Cl}=0.90-1.14 \%)$ in younger women (age $<50$ years) with a first ER-positive tumor to $1.89 \%(95 \% \mathrm{Cl}=1.61-$ $2.21 \%)$ in younger women with a first ER-negative tumor.

Conclusion: Declines in CBC risk are consistent with continued advances in breast cancer treatment. The updated estimates of cumulative incidence inform breast cancer patients and clinicians on the risk of CBC and may help guide treatment decisions.
\end{abstract}

Keywords: Breast cancer, Contralateral breast cancer, SEER

\footnotetext{
* Correspondence: cody.ramin@nih.gov

${ }^{1}$ Radiation Epidemiology Branch, Division of Cancer Epidemiology and

Genetics, National Cancer Institute, National Institutes of Health, Bethesda,

MD, USA

Full list of author information is available at the end of the article
}

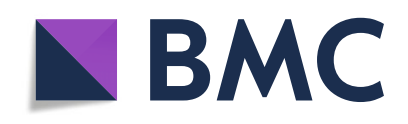

(- The Author(s). 2021 Open Access This article is licensed under a Creative Commons Attribution 4.0 International License, which permits use, sharing, adaptation, distribution and reproduction in any medium or format, as long as you give appropriate credit to the original author(s) and the source, provide a link to the Creative Commons licence, and indicate if changes were made. The images or other third party material in this article are included in the article's Creative Commons licence, unless indicated otherwise in a credit line to the material. If material is not included in the article's Creative Commons licence and your intended use is not permitted by statutory regulation or exceeds the permitted use, you will need to obtain permission directly from the copyright holder. To view a copy of this licence, visit http://creativecommons.org/licenses/by/4.0/ The Creative Commons Public Domain Dedication waiver (http://creativecommons.org/publicdomain/zero/1.0/) applies to the data made available in this article, unless otherwise stated in a credit line to the data. 


\section{Background}

In the USA, overall 5-year survival rates for breast cancer now exceed 90\% [1] and a growing number of breast cancer patients will become long-term survivors at risk for second cancers. Contralateral breast cancer (CBC) is the most common second cancer among breast cancer patients [2]. Although the number of women at risk for $\mathrm{CBC}$ is increasing, previous studies have reported an overall decrease in CBC incidence rates since the 1980s $[3,4]$. Specifically, CBC incidence has declined annually by 3\% from 1985 through 2006 in the USA [4]. Importantly, approaches to breast cancer treatment have evolved over the past several decades with the widespread uptake of adjuvant hormone therapy, including tamoxifen in the 1990s and aromatase inhibitors in the mid-2000s, advances in chemotherapy regimens including a shift towards taxane-containing drugs [5-7], and the introduction of trastuzumab to treat early-stage human epidermal growth factor receptor 2 (HER2)-positive tumors in 2005 [8, 9]. In addition, the uptake of contralateral prophylactic mastectomies in the USA has nearly tripled in the past decade to over $10 \%$ of invasive breast cancer patients undergoing the removal of the unaffected breast [10-12]. This increasing uptake of contralateral prophylactic mastectomies has occurred across all ages and stage at diagnosis $[11,12]$.

Thus, the aim of our study was to describe CBC risk in the USA across these periods of significant advances in treatment and to include assessment by HER2 status for the first time as well as immunohistochemistry (IHC)-defined breast cancer subtypes. For this study, we used nationally representative data from the National Cancer Institute's Surveillance, Epidemiology, and End Results (SEER) program, a large-scale and populationbased group of cancer registries with detailed records and long-term follow up, to examine CBC risk compared to the general population from 1992 to 2016 according to calendar year of diagnosis, age at diagnosis, and tumor characteristics for the first breast cancer. To help inform clinical decision making, we also calculated the 5-year cumulative incidence of $\mathrm{CBC}$ in the recent treatment era from 2004 to 2016 according to characteristics of the first breast cancer.

\section{Methods}

\section{Study population}

We obtained female breast cancer case and population data using the SEER 13 Registries Database excluding the Alaska Native Tumor Registry (November 2018 submission, 1992-2016) [13]. We used the SEER 13 Registries Database because it includes the time periods when there were major advances in breast cancer treatment and provides long-term follow-up to examine trends in $\mathrm{CBC}$ risk. We identified women aged 30 to 84 years who were diagnosed with a first primary unilateral invasive breast cancer with known laterality and who survived $\geq 1$ year without developing a second cancer. We excluded women aged $<30$ years given the relatively low number of breast cancers diagnosed prior to this age and women aged $\geq 85$ years due to under-reporting of second cancers among older patients [14]. Those diagnosed with a first breast cancer at stage IV or based on autopsy reports/death certificates only were not included. The analytic cohort included 419,818 women with invasive unilateral breast cancer who survived for $\geq$ 1 year and who were diagnosed between 1992 and 2015 and followed through 2016.

\section{Outcome assessment}

We defined $\mathrm{CBC}$ as an invasive second breast cancer diagnosed in the contralateral unaffected breast $\geq 12$ months after the first invasive breast cancer diagnosis. We excluded the first 12 months of follow-up to reduce potential misclassification of metastases or undetected synchronous bilateral breast cancer as CBC [4]. Followup time started 12 months after the diagnosis of the first breast cancer and continued until the second cancer diagnosis, death, loss to follow-up, or administrative censoring on December 31, 2016, whichever occurred first.

\section{Covariates}

Patient and tumor characteristics for the first breast cancer included calendar year of diagnosis, age at diagnosis, American Joint Committee on Cancer (AJCC) stage (I, II, III, IV), histology (ductal, lobular, mixed, other), estrogen receptor (ER) status (positive, negative, borderline, or unknown), HER2 status (positive, negative, borderline, or unknown), and IHC-defined breast cancer subtype (hormone receptor $[\mathrm{HR}]+/ \mathrm{HER} 2+$, HR+/HER2-, HR-/HER2+, HR-/HER2- [triple negative], or unknown). HR status was defined as a joint combination of ER and progesterone receptor (PR) status (i.e., $\mathrm{HR}+=$ $\mathrm{ER}+$ and/or $\mathrm{PR}+; \mathrm{HR}-=\mathrm{ER}-$ and $\mathrm{PR}-$ ). For breast cancer subtype, borderline tumors were categorized as unknown for HER2 status and positive for ER/PR status using the standard SEER algorithm. ER/PR status has been routinely collected in the SEER database since 1990 while collection of HER2 status began in 2010. Histologic categories were based on the International Classification of Diseases for Oncology, third edition (ICD-O-3) codes, and categorized as ductal (8500, 8523), lobular (8520, 8524), mixed ductal/lobular (8522), and other (all remaining codes). First course of treatment (radiation, chemotherapy, and hormone therapy) has been recorded in the SEER registries and categorized as known receipt (yes) and no or unknown receipt (no/unknown). Women without treatment and unknown treatment are combined in SEER data due to the limited sensitivity of 
treatment variables in the SEER registries [15]. Type of breast cancer surgery has been routinely recorded since 1998. We defined breast cancer surgery as none, breast conserving therapy, unilateral mastectomy, contralateral prophylactic mastectomy, or unknown. Contralateral prophylactic mastectomy was defined as the removal of the affected breast and the uninvolved contralateral breast.

\section{Statistical analysis}

We estimated standardized incidence ratios (SIRs, a measure of relative risk) and $95 \%$ confidence intervals (CIs) for $\mathrm{CBC}$ overall and according to characteristics of the first breast cancer. SIRs for CBC by HER2 status and subtype of the first breast cancer were also evaluated in a subgroup of women diagnosed with a first breast cancer between 2010 and 2015 and followed through 2016 . SIRs were calculated as the observed number of incident breast cancers (in the contralateral breast) compared to the expected number in the general population [16]. Expected breast cancers were derived from incidence rates in the 12 SEER registries stratified by race (White/unknown, Black, other), age at initial diagnosis (5-year groups), and calendar year (5-year intervals) [16]. We estimated 95\% confidence intervals using the Byar's approximation of the exact Poisson distribution [17].

To describe temporal trends in CBC risk, SIRs for CBC were stratified by calendar period of first breast cancer diagnosis (1992-1997, 1998-2003, 2004-2009, 20102015). We first conducted this analysis including all women to describe long-term trends in $\mathrm{CBC}$ risk among the general population of breast cancer survivors. We then estimated SIRs excluding patients with contralateral prophylactic mastectomies or unknown surgery type among those diagnosed with a first breast cancer from $1998+$ when type of breast cancer surgery was available in SEER. We did not exclude these patients in our main approach since we aimed to describe $\mathrm{CBC}$ risk on a population level and found that exclusion of women with contralateral prophylactic mastectomies did not substantially change our findings. Trends were examined overall and according to age at diagnosis $(<50$ years and $\geq 50$ years, as a proxy for menopausal status [18]) and ER status for the initial breast cancer. Trends by detailed categories of age at diagnosis $(<40,40$ to $<50,50$ to $<60,60$ to $<70$, $\geq 70$ years) for the first breast cancer were also described. Exploratory analyses examined trends by initial receipt of chemotherapy and hormone therapy. We also conducted several sensitivity analyses. First, we examined trends by time since first breast cancer diagnosis $(<5$ years, $\geq 5$ years). Second, we expanded CBC to include both in situ and invasive tumors. Third, we varied the definition of CBC to those diagnosed $\geq 6$ and $\geq 24$ months after the first breast cancer.
To provide an absolute measure of $\mathrm{CBC}$ risk in the recent treatment era, we estimated cumulative incidence of $\mathrm{CBC}$ among 1-year survivors diagnosed with a first breast cancer between 2004 and 2015 and followed through 2016. We estimated cumulative incidence of $\mathrm{CBC}$ overall and according to characteristics of the first breast cancer. We calculated the 5-year cumulative incidence of $\mathrm{CBC}$ from the index date using a competing risk approach to account for death and other second cancers as competing events $[19,20]$. We excluded women with contralateral prophylactic mastectomies or unknown surgery type from all estimates of cumulative incidence. As a sensitivity analysis, we defined $\mathrm{CBC}$ as those diagnosed $\geq 6$ months after the first breast cancer to estimate the impact of earlier detection.

All statistical tests were two-sided and $p$ values $<0.05$ were considered statistically significant. $P$ for trends were calculated using the smrby package in Stata. Analyses were performed using SEER* Stat software (version 8.3.5), Stata version 11 and 15 (StataCorp, College Station, TX, USA).

\section{Results}

Table 1 describes characteristics of the first breast cancer overall and by calendar period of diagnosis among 419,818 1-year survivors with a median follow-up of 7.9 years (range $1.00-24.9$ years). The mean age at first breast cancer diagnosis was 59 years and tumors were primarily early stage, ductal histology, and ER-positive. Characteristics of the first breast cancer were generally similar across calendar period of diagnosis. However, the proportion of first ER-positive tumors increased over time. From 1998 to 2003 and 2010 to 2015, the uptake of contralateral prophylactic mastectomies more than tripled from 2.9 to $11.8 \%$ of breast cancer patients, while the proportion of women undergoing breast conserving surgery or unilateral mastectomy decreased from 91.3 to $83.4 \%$.

We identified 12,986 cases of CBC among women diagnosed with a first breast cancer between 1992 and 2015 and followed through 2016 (Fig. 1). Breast cancer patients had approximately a 2 -fold increased risk of an incident breast cancer (in the contralateral breast) when compared to that expected in the general population $(\mathrm{SIR}=2.21,95 \% \mathrm{CI}=2.17-2.25)$ (Table 2). SIRs for CBC were highest among women diagnosed with a first breast cancer at age $<40$ years ( $\mathrm{SIR}=6.41,95 \% \mathrm{CI}=6.02-6.82)$, and after a first ER-negative tumor $(\mathrm{SIR}=3.05 ; 95 \% \mathrm{CI}=$ 2.94-3.16). CBC risk increased from over twofold in women diagnosed at stage I ( $\mathrm{SIR}=2.08,95 \% \mathrm{CI}=2.03$ 2.13) to nearly threefold in those diagnosed at stage III $(\mathrm{SIR}=2.97,95 \% \mathrm{CI}=2.83-3.11)$. SIRs by histologic type of the first breast cancer ranged between 2.06 and 2.49 with the highest SIR observed among mixed ductal/ 
Table 1 Descriptive characteristics of the first breast cancer among 1-year survivors of a first primary breast cancer in 12 SEER registries, 1992-2016

\begin{tabular}{|c|c|c|c|c|c|}
\hline \multirow[b]{3}{*}{ Characteristics of the first breast cancer } & \multirow{3}{*}{$\begin{array}{l}\text { Overall } \\
N=419,818\end{array}$} & \multicolumn{4}{|c|}{ Calendar period of first breast cancer diagnosis } \\
\hline & & $1992-1997$ & 1998-2003 & 2004-2009 & 2010-2015 \\
\hline & & $N=89,052$ & $N=107,103$ & $N=107,828$ & $N=115,835$ \\
\hline Overall, \% & 100.0 & 21.2 & 25.5 & 25.7 & 27.6 \\
\hline Year of diagnosis, mean years (SD) & $2004.0(6.8)$ & $1994.6(1.7)$ & $2000.5(1.7)$ & $2006.5(1.7)$ & $2012.5(1.7)$ \\
\hline \multicolumn{6}{|l|}{ Age at diagnosis, years, $\%$} \\
\hline$<40$ & 5.9 & 6.7 & 6.1 & 5.8 & 5.3 \\
\hline 40 to $<50$ & 20.4 & 20.7 & 20.8 & 21.4 & 18.8 \\
\hline 50 to $<60$ & 26.1 & 23.0 & 26.7 & 27.5 & 26.6 \\
\hline 60 to $<70$ & 24.3 & 23.4 & 21.9 & 23.6 & 27.9 \\
\hline$\geq 70$ & 23.3 & 26.2 & 24.6 & 21.7 & 21.4 \\
\hline Age at diagnosis, mean years (SD) & $58.8(12.7)$ & $59.2(13.1)$ & $58.8(12.9)$ & $58.4(12.6)$ & $59.0(12.2)$ \\
\hline \multicolumn{6}{|l|}{ Stage at diagnosis, \% } \\
\hline । & 50.7 & 50.9 & 50.9 & 50.2 & 50.7 \\
\hline$\|$ & 36.0 & 33.8 & 35.4 & 36.7 & 37.7 \\
\hline III & 13.3 & 15.4 & 13.7 & 13.1 & 11.6 \\
\hline \multicolumn{6}{|l|}{ Histology, \% } \\
\hline Ductal & 75.4 & 73.4 & 72.3 & 76.3 & 79.1 \\
\hline Lobular & 8.3 & 7.7 & 8.1 & 8.1 & 9.3 \\
\hline Mixed & 7.1 & 5.7 & 9.1 & 7.8 & 5.6 \\
\hline Other & 9.2 & 13.3 & 10.5 & 7.8 & 6.1 \\
\hline \multicolumn{6}{|l|}{ ER status, \% } \\
\hline Positive & 73.1 & 62.0 & 68.6 & 76.4 & 82.8 \\
\hline Negative & 18.6 & 20.2 & 18.6 & 19.8 & 16.0 \\
\hline Borderline/unknown & 8.3 & 17.7 & 12.8 & 3.7 & 1.2 \\
\hline \multicolumn{6}{|l|}{ Initial treatment receipt, \% } \\
\hline \multicolumn{6}{|l|}{ Surgery $^{a}$} \\
\hline None & 2.0 & - & 1.2 & 1.7 & 3.1 \\
\hline $\mathrm{BCS} /$ unilateral mastectomy & 87.9 & - & 91.3 & 89.5 & 83.4 \\
\hline Contralateral prophylactic mastectomy & 7.3 & - & 2.9 & 6.8 & 11.8 \\
\hline Unknown & 2.8 & - & 4.6 & 2.0 & 1.7 \\
\hline \multicolumn{6}{|l|}{ Radiation therapy } \\
\hline Yes & 54.2 & 45.0 & 55.3 & 56.8 & 58.0 \\
\hline No/unknown & 45.8 & 55.1 & 44.7 & 43.2 & 42.1 \\
\hline \multicolumn{6}{|l|}{ Chemotherapy } \\
\hline Yes & 40.5 & 31.3 & 41.9 & 45.0 & 42.0 \\
\hline No/unknown & 59.5 & 68.8 & 58.1 & 55.0 & 58.0 \\
\hline \multicolumn{6}{|l|}{ Hormone therapy } \\
\hline Yes & 42.9 & 32.5 & 37.4 & 43.2 & 55.6 \\
\hline No/unknown & 57.1 & 67.5 & 62.6 & 56.8 & 44.4 \\
\hline \multicolumn{6}{|l|}{ HER2 status ${ }^{b}, \%$} \\
\hline Positive & 14.5 & - & - & - & 14.5 \\
\hline Negative & 80.6 & - & - & - & 80.6 \\
\hline Borderline/unknown & 4.9 & - & - & - & 4.9 \\
\hline
\end{tabular}


Table 1 Descriptive characteristics of the first breast cancer among 1-year survivors of a first primary breast cancer in 12 SEER registries, 1992-2016 (Continued)

\begin{tabular}{|c|c|c|c|c|c|}
\hline \multirow[b]{3}{*}{ Characteristics of the first breast cancer } & \multirow{3}{*}{$\begin{array}{l}\text { Overall } \\
N=419,818\end{array}$} & \multicolumn{4}{|c|}{ Calendar period of first breast cancer diagnosis } \\
\hline & & 1992-1997 & $1998-2003$ & 2004-2009 & $2010-2015$ \\
\hline & & $N=89,052$ & $N=107,103$ & $N=107,828$ & $N=115,835$ \\
\hline \multicolumn{6}{|l|}{ Breast cancer subtype $^{b, c}, \%$} \\
\hline $\mathrm{HR}+/ \mathrm{HER} 2+$ & 10.2 & - & - & - & 10.2 \\
\hline HR+/HER2- & 70.3 & - & - & - & 70.3 \\
\hline HR-/HER2+ & 4.3 & - & - & - & 4.3 \\
\hline HR-/HER2- (Triple negative) & 10.2 & - & - & - & 10.2 \\
\hline Unknown & 5.0 & - & - & - & 5.0 \\
\hline
\end{tabular}

SEER, Surveillance, Epidemiology, and End Results; $E R$, estrogen receptor; $B C S$, breast conserving surgery; HER2, human epidermal growth factor receptor 2; $H R$, hormone receptor; $P R$, progesterone receptor

anformation on initial surgery was available for breast cancers diagnosed from $1998+(N=330,766)$

${ }^{b}$ HER2 status was routinely collected in 2010+. Estimates include first breast cancers diagnosed from 2010 to 2015 and followed through $2016(N=115,835)$

${ }^{\mathrm{C}} \mathrm{HR}+=\mathrm{ER}+$ and/or PR+; HR- = ER- and PR-

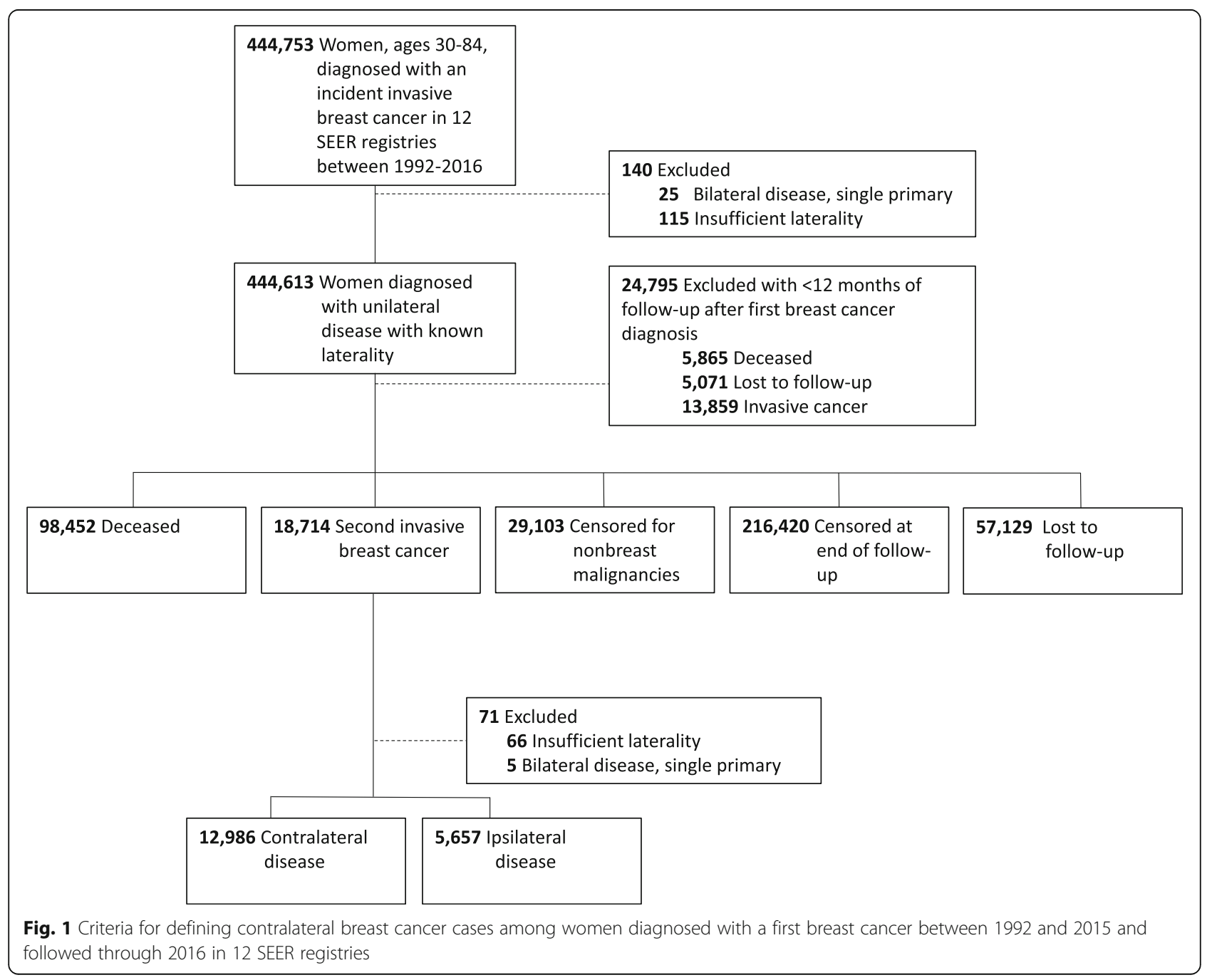


Table 2 SIRs for contralateral breast cancer among 1-year survivors of a first primary breast cancer in 12 SEER registries, 1992-2016

\begin{tabular}{|c|c|c|}
\hline $\begin{array}{l}\text { First breast cancer } \\
\text { characteristic }\end{array}$ & $\begin{array}{l}\text { No. of CBCs } \\
\text { (\%) }\end{array}$ & SIR $(95 \% \mathrm{CI})$ \\
\hline Overall & $12,986(100.0)$ & 2.21 (2.17 to 2.25$)$ \\
\hline \multicolumn{3}{|c|}{ Age at diagnosis, years } \\
\hline$<40$ & $1002(7.7)$ & 6.41 (6.02 to 6.82$)$ \\
\hline 40 to $<50$ & $2691(20.7)$ & 2.79 (2.69 to 2.90$)$ \\
\hline 50 to $<60$ & $3452(26.6)$ & 2.07 (2.00 to 2.14$)$ \\
\hline 60 to $<70$ & $3292(25.4)$ & 1.91 (1.85 to 1.98$)$ \\
\hline$\geq 70$ & 2549 (19.6) & $1.87(1.80$ to 1.94$)$ \\
\hline \multicolumn{3}{|l|}{ Time since diagnosis } \\
\hline$<5$ years & $4620(35.6)$ & 2.03 (1.97 to 2.09 ) \\
\hline$\geq 5$ years & $8366(64.4)$ & 2.32 (2.27 to 2.37$)$ \\
\hline \multicolumn{3}{|l|}{ Stage at diagnosis } \\
\hline 1 & $6899(53.1)$ & 2.08 (2.03 to 2.13$)$ \\
\hline$\|$ & $4364(33.6)$ & 2.21 (2.14 to 2.28$)$ \\
\hline III & $1723(13.3)$ & $2.97(2.83$ to 3.11$)$ \\
\hline \multicolumn{3}{|l|}{ Histology } \\
\hline Ductal & $9340(71.9)$ & $2.17(2.13$ to 2.21$)$ \\
\hline Lobular & $1037(8.0)$ & 2.06 (1.94 to 2.19$)$ \\
\hline Mixed & $1126(8.7)$ & 2.49 (2.35 to 2.64$)$ \\
\hline Other & $1483(11.4)$ & 2.44 (2.32 to 2.57$)$ \\
\hline \multicolumn{3}{|l|}{ ER status } \\
\hline Positive & $8372(64.5)$ & 1.98 (1.94 to 2.02$)$ \\
\hline Negative & $3024(23.3)$ & 3.05 (2.94 to 3.16$)$ \\
\hline \multicolumn{3}{|l|}{ Initial treatment } \\
\hline \multicolumn{3}{|l|}{ Radiation therapy } \\
\hline Yes & $7180(55.3)$ & 2.25 (2.20 to 2.30$)$ \\
\hline No/unknown & $5806(44.7)$ & 2.17 (2.11 to 2.23 ) \\
\hline \multicolumn{3}{|l|}{ Chemotherapy } \\
\hline Yes & $5086(39.2)$ & 2.49 (2.42 to 2.56$)$ \\
\hline No/unknown & $7900(60.8)$ & $2.06(2.01$ to 2.11$)$ \\
\hline \multicolumn{3}{|l|}{ Hormone therapy } \\
\hline Yes & $4442(34.2)$ & $1.88(1.83$ to 1.94$)$ \\
\hline No/unknown & $8544(65.8)$ & 2.43 (2.38 to 2.48 ) \\
\hline \multicolumn{3}{|l|}{ HER2 status ${ }^{a}$} \\
\hline Positive & $93(11.8)$ & $1.45(1.17$ to 1.78$)$ \\
\hline Negative & $646(82.2)$ & $1.57(1.45$ to 1.70$)$ \\
\hline \multicolumn{3}{|c|}{ Breast cancer subtype $e^{a, b}$} \\
\hline $\mathrm{HR}+/ \mathrm{HER} 2+$ & $66(8.4)$ & $1.47(1.14$ to 1.87$)$ \\
\hline $\mathrm{HR}+/ \mathrm{HER} 2-$ & $534(67.9)$ & $1.47(1.35$ to 1.60$)$ \\
\hline
\end{tabular}

Table 2 SIRs for contralateral breast cancer among 1-year survivors of a first primary breast cancer in 12 SEER registries, 1992-2016 (Continued)

\begin{tabular}{lll}
\hline $\begin{array}{l}\text { First breast cancer } \\
\text { characteristic }\end{array}$ & $\begin{array}{l}\text { No. of CBCs } \\
\mathbf{( \% )}\end{array}$ & SIR $(\mathbf{9 5 \%} \mathbf{C l})$ \\
\hline HR-/HER2+ & $27(3.4)$ & $1.42(0.94$ to 2.07$)$ \\
$\begin{array}{l}\text { HR-/HER2- } \\
\text { (triple negative) }\end{array}$ & $111(14.1)$ & $2.43(2.00$ to 2.93$)$ \\
\hline
\end{tabular}

SEER, Surveillance, Epidemiology, and End Results; $C B C$, contralateral breast cancer; SIRs, standardized incidence ratios; $\mathrm{Cl}$, confidence interval; $E R$, estrogen receptor; $H E R 2$, human epidermal growth factor receptor $2 ; H R$, hormone receptor; $P R$, progesterone receptor

aHER2 status routinely collected in 2010 and onwards. Estimates include first breast cancers diagnosed between 2010 and 2015 and followed through 2016 (no. of first breast cancers $=115,835$; no. of contralateral breast cancers $=786$; overall $\mathrm{SIR}=1.57,95 \% \mathrm{Cl}=1.46-1.68$ )

${ }^{\mathrm{b}} \mathrm{HR}+=\mathrm{ER}+$ and/or PR+; HR- $=\mathrm{ER}-$ and $\mathrm{PR}-$

lobular histology. SIRs were approximately 2-fold regardless of time since diagnosis with a slightly higher SIR observed with longer latency $(<5$ years: $\operatorname{SIR}=2.03$, $95 \% \mathrm{CI}=1.97-2.09 ; \geq 5$ years: $\mathrm{SIR}=2.32,95 \% \mathrm{CI}=2.27$ 2.37). Compared to the overall SIR of 2.21, SIRs for CBC were slightly higher among women treated with chemotherapy $(\mathrm{SIR}=2.49,95 \% \mathrm{CI}=2.42-2.56)$ and lower among women with hormone therapy $(\mathrm{SIR}=1.88,95 \%$ $\mathrm{CI}=1.83-1.94)$.

In the subset of women diagnosed with a first breast cancer between 2010 and 2015 and followed through 2016 (overall SIR $=1.57 ; 95 \% \mathrm{CI}=1.46-1.68$; Table 2), SIRs for CBC were similar by HER2 status of the first breast cancer (HER2-positive: $\mathrm{SIR}=1.45,95 \% \mathrm{CI}=1.17$ 1.78; HER2-negative: $\mathrm{SIR}=1.57,95 \% \mathrm{CI}=1.45-1.70$ ). $\mathrm{CBC}$ risk was highest after a first triple-negative breast cancer $(\mathrm{SIR}=2.43,95 \% \mathrm{CI}=2.00-2.93$; $\mathrm{SIRs}$ for the other subtypes ranged from 1.42 to 1.47 ).

SIRs for CBC significantly declined over calendar period of diagnosis (Fig. 2; Additional file 1: Supplementary Table 1). The overall SIR for CBC decreased from $2.49(95 \% \mathrm{CI}=2.42-2.56)$ in $1992-1997$ to $1.57(95 \%$ $\mathrm{CI}=1.46-1.68)$ in 2010-2015 ( $p$-trend $<0.001)$. This decreasing temporal trend in $\mathrm{CBC}$ risk was observed regardless of age at diagnosis and ER status of the first breast cancer ( $p$-trends <0.001). Trends in CBC risk differed with joint stratification by age at diagnosis and ER status of the first breast cancer. Specifically, we observed a significant decreasing trend in $\mathrm{CBC}$ risk regardless of age at diagnosis after an ER-positive tumor ( $p$-trends $<0.001)$ but not after an ER-negative tumor ( $p$-trend for $<50$ years $=0.23$; $p$-trend for $\geq 50$ years $=$ 0.31 ). The observed overall decline in CBC risk after an ER-negative tumor appeared driven by younger women diagnosed with a first breast cancer between 2010 and 2015. SIRs were overall slightly higher in magnitude with exclusion of women with contralateral prophylactic mastectomies, but similar temporal trends were observed even with the exclusion of these patients. Trends 


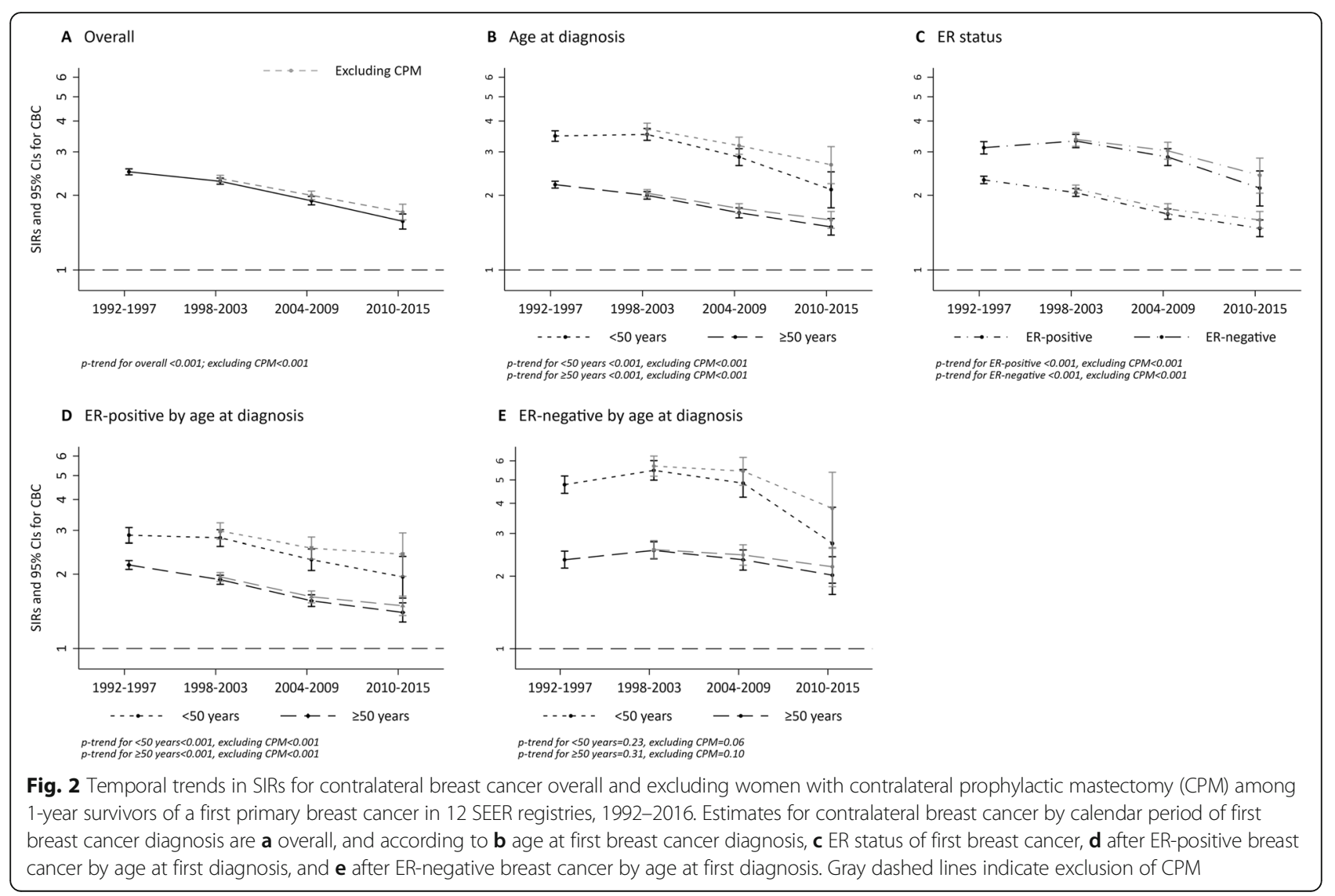

by detailed categories of age at diagnosis and ER status for the first breast cancer showed significant declines in SIRs among all age groups except for age $<40$ years and some variability by ER status with significant trends only observed among ER-positive patients (Additional file 1: Supplementary Fig. 1).

Overall significant decreasing trends in SIRs remained when analyses were restricted to $<5$ years since first diagnosis with trends even more pronounced among women aged $<50$ years at first diagnosis and those diagnosed with a first ER-negative tumor (Additional file 1: Supplementary Table 2). Significant declines in risk were also observed when analyses included women diagnosed with in situ CBC (Additional file 1: Supplementary Fig. 2). Trends in SIRs were similar when we varied the definition of $C B C$ to those diagnosed $\geq 6$ or $\geq 24$ months after the first breast cancer (data not shown). Exploratory analyses suggest that $\mathrm{CBC}$ risk declined over time among women treated with chemotherapy, particularly among women diagnosed with a first breast cancer prior to age 50 years (Additional file 1: Supplementary Fig. 3), and among women treated with hormone therapy (Additional file 1: Supplementary Fig. 4).

Table 3 shows estimated 5 -year cumulative incidence of $\mathrm{CBC}$ in women diagnosed with a first breast cancer in the recent treatment era (2004 to 2015 and followed through
2016). Breast cancer patients had an overall 5 -year cumulative incidence of $\mathrm{CBC}$ of $1.31 \%$ (95\% $\mathrm{CI}=1.26-1.37 \%$ ). The highest 5 -year cumulative incidence was observed after a first ER-negative tumor in women aged $<50$ years at diagnosis $(1.89 \%, 95 \% \mathrm{CI}=1.61-2.21 \%)$ and lowest after an ER-positive tumor in women aged $<50$ years at diagnosis $(1.01 \%, 95 \% \mathrm{CI}=0.90-1.14 \%)$. In a subgroup of women diagnosed with a first breast cancer between 2010 and 2015 (follow-up through 2016), the 5-year cumulative incidence did not differ by HER2 status and the highest cumulative incidence was observed after a first triplenegative breast tumor (1.71\%, 95\% CI $=1.38-2.09 \%$ ). Estimates of cumulative incidence were overall similar, but slightly higher, among 6-month survivors (Additional file 1: Supplementary Table 3).

\section{Discussion}

In this large population-based study from 1992 to 2016, we found that breast cancer patients had approximately twice the risk of an incident breast cancer (in the contralateral breast) when compared to that expected in the general population. However, our analysis showed a decline in $\mathrm{CBC}$ risk over calendar time, consistent with advances in breast cancer treatment, particularly after a first ER-positive breast cancer. Notably, the 5-year cumulative incidence of CBC 
Table 3 Cumulative incidence of contralateral breast cancer among 1-year survivors of a first primary breast cancer diagnosed in the recent treatment era between 2004 and 2015 (followed through to 2016) in 12 SEER registries

\begin{tabular}{|c|c|}
\hline First breast cancer characteristic & $\begin{array}{l}\text { 5-year cumulative } \\
\text { incidence }(95 \% \mathrm{Cls})^{\mathrm{a}}\end{array}$ \\
\hline Overall & $1.31 \%(1.26$ to $1.37 \%)$ \\
\hline \multicolumn{2}{|l|}{ Age at diagnosis, years } \\
\hline$<40$ & $1.54 \%$ (1.27 to $1.85 \%)$ \\
\hline 40 to $<50$ & $1.15 \%(1.03$ to $1.28 \%)$ \\
\hline 50 to $<60$ & $1.24 \%(1.13$ to $1.35 \%)$ \\
\hline 60 to $<70$ & $1.33 \%(1.22$ to $1.45 \%)$ \\
\hline$\geq 70$ & $1.47 \%(1.35$ to $1.60 \%)$ \\
\hline \multicolumn{2}{|l|}{ Stage at diagnosis } \\
\hline । & $1.32 \%(1.24$ to $1.40 \%)$ \\
\hline$\|$ & $1.17 \%(1.08$ to $1.26 \%)$ \\
\hline III & $1.73 \%(1.55$ to $1.93 \%)$ \\
\hline \multicolumn{2}{|l|}{ ER status } \\
\hline Positive & $1.19 \%(1.13$ to $1.26 \%)$ \\
\hline Negative & $1.81 \%(1.66$ to $1.98 \%)$ \\
\hline \multicolumn{2}{|l|}{ ER status and age at diagnosis } \\
\hline \multicolumn{2}{|l|}{ ER-positive } \\
\hline$<50$ years & $1.01 \%(0.90$ to $1.14 \%)$ \\
\hline$\geq 50$ years & $1.24 \%(1.17$ to $1.32 \%)$ \\
\hline \multicolumn{2}{|l|}{ ER-negative } \\
\hline$<50$ years & $1.89 \%(1.61$ to $2.21 \%)$ \\
\hline$\geq 50$ years & $1.78 \%(1.60$ to $1.97 \%)$ \\
\hline \multicolumn{2}{|l|}{ HER2-status $^{\mathrm{b}}$} \\
\hline Positive & $1.35 \%(1.05$ to $1.71 \%)$ \\
\hline Negative & $1.33 \%(1.21$ to $1.45 \%)$ \\
\hline \multicolumn{2}{|l|}{ Breast cancer subtype $e^{b, c}$} \\
\hline $\mathrm{HR}+/ \mathrm{HER} 2+$ & $1.39 \%(1.02$ to $1.84 \%)$ \\
\hline $\mathrm{HR}+/ \mathrm{HER} 2-$ & $1.27 \%(1.15$ to $1.41 \%)$ \\
\hline HR-/HER2+ & $1.27 \%$ (0.80 to $1.94 \%)$ \\
\hline HR-/HER2- (triple negative) & $1.71 \%$ (1.38 to $2.09 \%)$ \\
\hline
\end{tabular}

The recent treatment era included 198,496 women diagnosed with a first primary breast cancer between 2004 and 2015 and 3179 CBC cases developed through 2016. Women with contralateral prophylactic mastectomies or unknown type of surgery were excluded from all estimates of cumulative incidence SEER, Surveillance, Epidemiology, and End Results; Cl, confidence interval; ER, estrogen-receptor; $H E R 2$, human epidermal growth factor receptor $2 ; H R_{a}$ hormone receptor; $P R$, progesterone receptor

${ }^{a}$ Cumulative incidence was calculated from the index date (the first 12 months after the initial breast cancer diagnosis were excluded)

${ }^{b}$ HER2-status and breast cancer subtype were estimated in a subgroup of women diagnosed with a first cancer between 2010 and 2015 and followed through $2016(N=100,153 ; C B C=762$; overall 5-year cumulative incidence $=1.34 \%(1.23-1.45 \%)$

${ }^{\mathrm{C} H R+}=\mathrm{ER}+$ and/or PR+; HR- = ER- and PR-

was low, ranging from 1 to $2 \%$, among women diagnosed with a first breast cancer during the most recent treatment era.
Previous studies examining trends in CBC incidence among US women have reported a decline since the early 1980s through 2006 [3, 4]. Our study extended these findings by 10 years into the modern treatment era and expanded results by examining $\mathrm{CBC}$ risk according to characteristics of the first breast cancer, including HER2 status and IHC-defined subtype. In addition, we extended previous findings by calculating SIRs to examine trends in $\mathrm{CBC}$ risk relative to the general population. The calculation of SIRs extracts the effect of treatment from broader changes in breast cancer risk factors (e.g., parity, hormone use, and obesity) which may impact both first and second breast cancer risk. Furthermore, we were able to examine the effect of contralateral prophylactic mastectomies on temporal trends in $\mathrm{CBC}$ risk. Our finding that declines in $\mathrm{CBC}$ risk remained even with the exclusion of women with contralateral prophylactic mastectomies suggests that decreases in $\mathrm{CBC}$ risk are likely due to advances in systemic therapies.

In our study, we observed that $\mathrm{CBC}$ risk after an ERpositive tumor has continued to decline past 2006, the end of our previous follow-up period [4]. The widespread introduction of aromatase inhibitors in the mid2000 s likely contributed to this continuing decline among older women ( $\geq 50$ years) as randomized clinical trials have shown a greater reduction in CBC with aromatase inhibitors as compared to tamoxifen [21]. In younger ER-positive women ( $<50$ years), we found that the decline in $\mathrm{CBC}$ risk was not completely driven by the increase in prophylactic mastectomies, which suggests a continuing impact of the widespread use of tamoxifen $[22,23]$ and possibly changes in chemotherapy regimens $[6,7]$.

Interestingly, we observed an overall decline in $\mathrm{CBC}$ risk after an ER-negative tumor which differs from previously reported trends through 2006, where there were no clear decreases in CBC incidence after an ERnegative breast cancer [4]. In our study, the observed decline in $\mathrm{CBC}$ risk after an ER-negative tumor appeared among women diagnosed with a first breast cancer in 2004 to 2009 with a further decline among those diagnosed between 2010 and 2015, particularly among those aged $<50$ years. Further advances in chemotherapy, such as a shift towards taxane-based chemotherapy in the mid-2000s, might have partially driven the observed decline in CBC risk after an ER-negative tumor [6, 7]. A recent study conducted among Dutch women diagnosed with a first breast cancer between 2003 and 2010 found that taxane-containing chemotherapy was associated with a strong reduction in $\mathrm{CBC}$ risk compared to no chemotherapy ( $\mathrm{HR}=0.48,95 \% \mathrm{CI}=0.36-0.62)$ [6]. Further studies are needed to confirm these findings and to elucidate the potential role of chemotherapy regimens on $\mathrm{CBC}$ risk. 
In our study, we observed a 5-year cumulative incidence of $\mathrm{CBC}$ of $1.31 \%$ for women diagnosed with a first breast cancer in the recent treatment era. These results are substantially lower than earlier studies [24-26]. However, previous studies included women diagnosed with a first breast cancer between the 1930s and mid1990s, and thus, largely prior to adjuvant hormone treatments and modern chemotherapy, and possibly also when the proportion of ER-negative tumors was higher [27]. Our 5-year cumulative incidence estimates, however, are consistent with more recent studies from other countries with similar treatment patterns [6,28-30].

This is the first study to our knowledge to provide population-based estimates of 5-year cumulative incidence of CBC in US breast cancer patients according to HER2 status and breast cancer subtype, which only became available in the SEER registries starting in 2010. Although we found no difference in the 5-year cumulative incidence by HER2 status of the first tumor, we observed the highest 5-year cumulative incidence of CBC after a triple-negative tumor. These results differ slightly from the previous Dutch study [6] which reported a higher 5-year cumulative incidence of CBC after HER2negative disease $(1.9 \%, 95 \% \mathrm{CI}=1.8-2.0 \%)$ compared to HER2-positive disease $(1.5 \%, 95 \% \mathrm{CI}=1.3-1.7 \%)$. To date, clinical trial data in women with early stage HER2positive breast cancer have shown no difference in $\mathrm{CBC}$ incidence among those treated with versus without trastuzumab [31]. Future studies with long-term follow-up are needed to examine the impact of treatment on CBC risk in early-stage HER2-positive patients.

The strengths of this study include the large-scale and population-based design with almost 13,000 CBCs, longterm follow-up from 1992 to 2016, and detailed tumor characteristics, which provided the opportunity to assess $\mathrm{CBC}$ risk and temporal trends in risk by characteristics of the first breast cancer. In addition, we had surgical data on the removal of the uninvolved contralateral breast and were therefore able to describe the overall limited impact of contralateral prophylactic mastectomies on the declining trends in $\mathrm{CBC}$ risk. There were also several limitations to our analysis including lack of detailed treatment data and individual-level risk factors. Due to under ascertainment of cancer treatment in the SEER registries, we were unable to directly compare $\mathrm{CBC}$ risk among women who did and did not receive treatment. Importantly, specificity of treatment data in SEER registries is high and therefore it is unlikely that known receipt of treatment is misclassified [15]. In addition, although we assumed that $\mathrm{CBC}$ was not a metastatic lesion or local recurrence of the original breast cancer, it is possible that CBC was misclassified [32-34]. However, we excluded the first 12 months of follow-up to reduce this potential misclassification.
Furthermore, our results were similar when we varied the criteria to define $\mathrm{CBC}$ as those occurring $\geq 6$ or 24 months after the first breast cancer.

\section{Conclusions}

In summary, the decline in $\mathrm{CBC}$ risk in breast cancer patients is likely related to continued advances in systemic breast cancer treatment. Although breast cancer patients had an overall increased risk of developing an incident breast cancer (in the contralateral breast) when compared to that expected in the general population, the current probability of developing $\mathrm{CBC}$ at 5 years was low $(1-2 \%)$. These estimates can further inform breast cancer patients and clinicians on the risk of $\mathrm{CBC}$ and help guide treatment decisions.

\section{Supplementary Information}

The online version contains supplementary material available at https://doi. org/10.1186/s13058-021-01400-3.

Additional file 1. Contains supplementary tables and figures.

\begin{abstract}
Abbreviations
CBC: Contralateral breast cancer; SIR: Standardized incidence ratio; $\mathrm{Cl}$ : Confidence interval; ER : Estrogen receptor; HER2: Human epidermal growth factor receptor 2; HR: Hormone Receptor;

IHC: Immunohistochemistry
\end{abstract}

\section{Acknowledgements}

Not applicable.

\section{Authors' contributions}

$\mathrm{CR}, \mathrm{GG}$, and $\mathrm{ABdG}$ contributed to the study concept and design. CR contributed to the acquisition of the data. All authors contributed to the analysis and interpretation of the data. CR and $A B d G$ contributed to drafting the manuscript. All authors contributed to the critical revision of the manuscript. All authors read and approved the final manuscript.

\section{Funding}

This work was supported by the Intramural Research Program and the Cancer Prevention Fellowship Program of the National Cancer Institute at the National Institutes of Health. The funders had no role in the design of the study and collection, analysis, and interpretation of the data and in the writing of the manuscript. Open Access funding provided by the National Institutes of Health (NIH).

\section{Availability of data and materials}

The datasets analyzed during the current study are available from the National Cancer Institute's Surveillance, Epidemiology and End Results program database: https://seer.cancer.gov/data/access.html

\section{Ethics approval and consent to participate}

This study used de-identified data from the National Cancer Institute's Surveillance, Epidemiology and End Results program and informed consent was not required.

\section{Consent for publication}

Not applicable.

\section{Competing interests}

The authors declare that they have no competing interests.

\section{Author details}

${ }^{1}$ Radiation Epidemiology Branch, Division of Cancer Epidemiology and Genetics, National Cancer Institute, National Institutes of Health, Bethesda, 
MD, USA. ${ }^{2}$ Integrative Tumor Epidemiology Branch, Division of Cancer Epidemiology and Genetics, National Cancer Institute, National Institutes of Health, Bethesda, MD, USA.

Received: 14 August 2020 Accepted: 25 January 2021

Published online: 17 February 2021

\section{References}

1. American Cancer Society. Breast cancer facts \& figures, 2019-2020. Atlanta: American Cancer Society, Inc.; 2019.

2. Curtis RE, Hankey BF, Hoover RN. New malignancies following breast cancer. In: Curtis RE, Ron E, LAG R, Hacker DG, Edwards BK, Tucker MA, Fraumeni Jr JF, editors. New malignancies among cancer survivors: SEER Cancer Registries, 1973-2000. Bethesda: National Cancer Institute; NIH publication 05-5302; 2006:181-205.

3. Bernstein JL, Lapinski RH, Thakore SS, Doucette JT, Thompson WD. The descriptive epidemiology of second primary breast cancer. Epidemiology. 2003;14(5):552-8.

4. Nichols HB, González ABd, Rosenberg PS, Anderson WF. Declining incidence of contralateral breast cancer in the United States from 1975 to 2006. J Clin Oncol. 2011;29(12):1564-9.

5. Early Breast Cancer Trialists' Collaborative Group. Polychemotherapy for early breast cancer: an overview of the randomised trials. Lancet. 1998; 352(9132):930-42.

6. Kramer I, Schaapveld M, Oldenburg HSA, Sonke GS, McCool D, van Leeuwen FE, Van de Vijver KK, Russell NS, Linn SC, Siesling S et al. The influence of adjuvant systemic regimens on contralateral breast cancer risk and receptor subtype. J Natl Cancer Inst. 2019;111(7):709-18.

7. Giordano SH, Lin Y-L, Kuo YF, Hortobagyi GN, Goodwin JS. Decline in the use of anthracyclines for breast cancer. J Clin Oncol. 2012;30(18):2232-9.

8. Romond EH, Perez EA, Bryant J, Suman VJ, Geyer CE, Davidson NE, Tan-Chiu E, Martino S, Paik S, Kaufman PA, et al. Trastuzumab plus adjuvant chemotherapy for operable HER2-positive breast cancer. N Engl J Med. 2005;353(16):1673-84.

9. Piccart-Gebhart MJ, Procter M, Leyland-Jones B, Goldhirsch A, Untch M, Smith I, Gianni L, Baselga J, Bell R, Jackisch C, et al. Trastuzumab after adjuvant chemotherapy in HER2-positive breast cancer. N Engl J Med. 2005; 353(16):1659-72

10. Murphy JA, Milner TD, O'Donoghue JM. Contralateral risk-reducing mastectomy in sporadic breast cancer. Lancet Oncol. 2013;14(7):e262-9.

11. Wong SM, Freedman RA, Sagara Y, Aydogan F, Barry WT, Golshan M. Growing use of contralateral prophylactic mastectomy despite no improvement in long-term survival for invasive breast cancer. Ann Surg. 2017;265(3):581-9.

12. Kummerow KL, Du L, Penson DF, Shyr Y, Hooks MA. Nationwide trends in mastectomy for early-stage breast cancer. JAMA Surgery. 2015;150(1):9-16.

13. Surveillance, Epidemiology, and End Results (SEER) Program (www.seer. cancer.gov) SEER*Stat Database: Incidence - SEER 13 Regs excluding AK Research Data, Nov 2018 Sub (1992-2016) < Katrina/Rita Population Adjustment> - Linked To County Attributes - Total U.S., 1969-2017 Counties, National Cancer Institute, DCCPS, Surveillance Research Program, released April 2019, based on the November 2018 submission.

14. Fraumeni JF, Curtis RE, Edwards BK, Tucker MA: Introduction. In: Curtis RE, Freedman MD, Ron E, Ries LA, Hacker D, Edwards BK, Tucker MA, Fraumeni $J F$, editors. New malignancies among cancer survivors: SEER cancer registries, 1973-2000. Bethesda, MD: National Cancer Institute, NIH publication 05-5302; 2006: 1-7.

15. Noone A-M, Lund JL, Mariotto A, Cronin K, McNeel T, Deapen D, Warren JL. Comparison of SEER treatment data with medicare claims. Med Care. 2016; 54(9):e55-64.

16. Curtis RE, Ries LA: Methods. In: Curtis RE, Freedman MD, Ron E, Ries LA, Hacker DG, Edwards BK, Tucker MA, Fraumeni JF, editors. New malignancies among cancer survivors: SEER cancer registries, 1973-2000. Bethesda: National Cancer Institute, NIH publication 05-5302; 2006: 9-13.

17. Breslow NE, Day NE: Statistical methods in cancer research. Volume II: The design and analysis of cohort studies. IARC Scientific Publication 82; 1987.

18. Hill K. The demography of menopause. Maturitas. 1996;23(2):113-27.

19. Gooley TA, Leisenring W, Crowley J, Storer BE. Estimation of failure probabilities in the presence of competing risks: new representations of old estimators. Stat Med. 1999;18(6):695-706.
20. Coviello V, Boggess M. Cumulative incidence estimation in the presence of competing risks. Stata J. 2004:4:103-12

21. Early Breast Cancer Trialists' Collaborative Group. Aromatase inhibitors versus tamoxifen in early breast cancer: patient-level meta-analysis of the randomised trials. Lancet. 2015;386(10001):1341-52.

22. Gierach GL, Curtis RE, Pfieffer RM, Mullooly M, Ntowe EA, Hoover RN, Nyante SJ, Feigelson HS, Glass AG, de Gonzalez AB. Association of adjuvant tamoxifen and aromatase inhibitor therapy with contralateral breast cancer risk among us women with breast cancer in a general community setting. JAMA Oncol. 2017;3(2):186-93.

23. Early Breast Cancer Trialists' Collaborative Group. Relevance of breast cancer hormone receptors and other factors to the efficacy of adjuvant tamoxifen: patient-level meta-analysis of randomised trials. Lancet. 2011;378(9793):771-84.

24. Healey EA, Cook EF, Orav EJ, Schnitt SJ, Connolly JL, Harris JR. Contralateral breast cancer: clinical characteristics and impact on prognosis. J Clin Oncol. 1993;11(8):1545-52.

25. Peto J, Mack TM. High constant incidence in twins and other relatives of women with breast cancer. Nat Genet. 2000;26(4):411-4.

26. Gao X, Fisher SG, Emami B. Risk of second primary cancer in the contralateral breast in women treated for early-stage breast cancer: a population-based study. Int J Radiation Oncol Biol Physics. 2003;56(4):1038-45.

27. Anderson WF, Katki HA, Rosenberg PS. Incidence of breast cancer in the United States: current and future trends. J Natl Cancer Inst. 2011;103(18): 1397-402.

28. Aalders KC, van Bommel ACM, van Dalen T, Sonke GS, van Diest PJ, Boersma $L$, van der Heiden, van der Loo M. Contemporary risks of local and regional recurrence and contralateral breast cancer in patients treated for primary breast cancer. Eur J Cancer. 2016, 63:118-126.

29. Hooning MJ, Aleman BMP, Hauptmann M, Baaijens MHA, Klijn JGM, Noyon $\mathrm{R}$, Stovall $\mathrm{M}$, van Leeuwen FE. Roles of radiotherapy and chemotherapy in the development of contralateral breast cancer. J Clin Oncol. 2008, 26(34): 5561-5568.

30. Schaapveld M, Visser O, Louwman WJ, Willemse PHB, de Vries EGE, van der Graaf WTA, Otter R, Coebergh JWW, van Leeuwen FE. The impact of adjuvant therapy on contralateral breast cancer risk and the prognostic significance of contralateral breast cancer: a population based study in the Netherlands. Breast Cancer Res Treat. 2008:110(1):189-97.

31. Cameron D, Piccart-Gebhart MJ, Gelber RD, Procter M, Goldhirsch A, de Azambuja E, Castro G, Untch M, Smith I, Gianni L, et al. 11 years' follow-up of trastuzumab after adjuvant chemotherapy in HER2-positive early breast cancer: final analysis of the HERceptin Adjuvant (HERA) trial. Lancet. 2017; 389(10075):1195-205.

32. Janschek E, Kandioler-Eckersberger D, Ludwig C, Kappel S, Wolf B, Taucher S, Rudas M, Gnant M, Jakesz R. Contralateral breast cancer: molecular differentiation between metastasis and second primary cancer. Breast Cancer Res Treat. 2001;67(1):1-8.

33. Begg CB, Ostrovnaya I, Geyer FC, Papanastasiou AD, Ng CKY, Sakr RA, Bernstein $J \mathrm{~L}$, Burke KA, King TA, Piscuoglio S, et al. Contralateral breast cancers: independent cancers or metastases? Int J Cancer. 2018;142(2):347-56.

34. Klevebring D, Lindberg J, Rockberg J, Hilliges C, Hall P, Sandberg M, Czene $K$. Exome sequencing of contralateral breast cancer identifies metastatic disease. Breast Cancer Res Treat. 2015;151(2):319-24.

\section{Publisher's Note}

Springer Nature remains neutral with regard to jurisdictional claims in published maps and institutional affiliations.

Ready to submit your research? Choose BMC and benefit from:

- fast, convenient online submission

- thorough peer review by experienced researchers in your field

- rapid publication on acceptance

- support for research data, including large and complex data types

- gold Open Access which fosters wider collaboration and increased citations

- maximum visibility for your research: over $100 \mathrm{M}$ website views per year

At $\mathrm{BMC}$, research is always in progress.

Learn more biomedcentral.com/submissions 